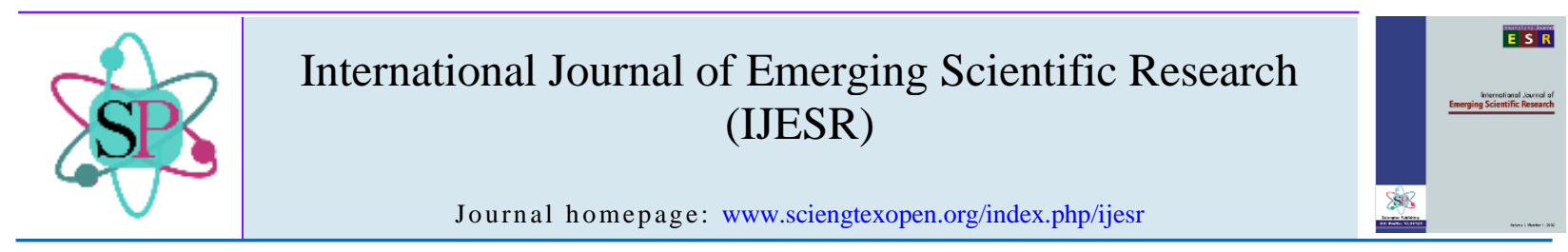

\title{
Impacts of Ambient Temperature Change on the Breakdown Voltage of a Distribution Transformer
}

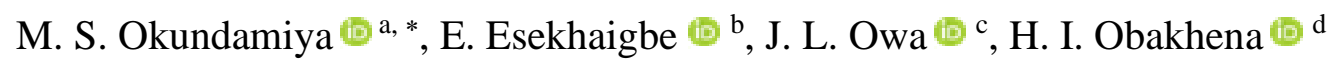 \\ a,b,d Department of Electrical \& Electronic Engineering, Ambrose Alli University, Ekpoma, Nigeria \\ ${ }^{c}$ Benin Electricity Distribution Company, Agbor, Delta State, Nigeria
}

\section{Authors' Contributions}

This work was carried out in collaboration between authors. The revised manuscript was read and approved by all authors.

\section{ARTICLE INFO}

Article history:

Received 21 April 2021

Received in revised form

8 May 2021

Accepted 11 May 2021

Available online

12 May 2021

Keywords:

Ambient temperature

Breakdown voltage

Dielectric strength

Distribution transformers

Insulation system

\section{ABSTRACT}

The aim of this paper is to determine the effects of ambient temperature variation on the breakdown voltage of a distribution transformer. Three different insulation oil samples (naphtha mineral, paraffin mineral and silicon base transformer oil) were collected from six distribution transformers $(300-500 \mathrm{kVA})$ across two business units (Asaba and Ugbowo) of Benin Electricity Distribution Company during May and June, 2017. The oil samples were analysed using the $60 \mathrm{kV}$ Megger OST60PB portable oil tester, to determine the trend of breakdown voltage of the oil insulation under varying temperature. A $3^{\text {rd }}$ order polynomial model was deduced for each sample type with coefficient of determination within the range of $96.99-99.95 \%$. The observed average breakdown voltage is $43.6 \mathrm{kV}$ (for naphtha base mineral transformer oil), $42.2 \mathrm{kV}$ (for paraffin base mineral transformer oil) and $46.8 \mathrm{kV}$ (for silicon base transformer oil) within the temperature range $\left(26^{\circ} \mathrm{C}-32^{\circ} \mathrm{C}\right)$. The result indicates that the breakdown voltages of the considered transformer oil types are satisfactory but the silicon base transformer oil has the best breakdown voltage.

\section{Introduction}

A transformer has a limited lifespan; yet, unlike other machines, it has no moving parts, apart from the cooling fans, tap changers or pump motors. Therefore, the transformer power outages are not as a result of wear out. Rather, the power outages could be due to deterioration of the insulation over time. The insulation system is one component of transformer, which once subjected to either normal or abnormal conditions (internal and external) or both have a corresponding effect that determine the healthiness of the transformer [1]-[3]. Testing the breakdown voltage and dielectric strength of a transformer oil are used for the assessment of the oil insulation level [4]. The insulation of a transformer can be subjected to different kinds of stresses such a thermal, electromagnetic and mechanical, to mention but a few [5].

Transformer insulation weakens continually over time, under the influence of stress and atmospheric conditions (oxygen and moisture). These effects on the insulation in the long run can lead to transformer failure. A case study analysis was carried out in [6] to determine the likely causes of failures in distribution transformers in India during the period (2010-2015). The statistical analysis showed that insulation failure is a major cause of breakdown of transformer. An independent study [7] on performance of the transformer

* Corresponding author

E-mail address: msokundamiya@aauekpoma.edu.ng

https://doi.org/10.37121/ijesr.v2.155 
liquid insulation system at varying atmospheric conditions established that the main opponent of insulation system is water. If the transformer failure can be predicted with a high degree of precision, unexpected failure can be reduced [8].

Generally, the ageing of insulation oil can be viewed as a chemical reaction that occurs at a rate that is being affected by electrical, thermal and chemical stresses. Chemical reactions generally result in products whose characteristics (physical and chemical) differ from the parent material [9]. For that reason, the physical and chemical characterisation of the reaction product may be used to ascertain the strength of the insulation material as well as the transformer. Besides, it is feasible to approximate the degree of insulation damage by monitoring reaction product [10]. The oil insulation test can be used to determine the breakdown voltage of transformer oil. This is done to ascertain the behaviour of the dielectric strength of the insulation oil sample when operating in a temperate region. The establishment of the breakdown voltage can help decide the type of oil that is best for use as the climatic condition are changing, since the operating temperature of the transformer could vary significantly [11]. The analysis of reaction products can provide valuable information on oil insulation system.

Analysis of the effects of transformer oil insulation level tend to analyse how different climatic conditions in which transformers are operated affects transformer performance in distribution network [12]. Hashmi et al. [13] studied the effect of climate change on different transformers loading conditions. The aim was to examine the likelihood of extreme operating conditions. As observed, a rise in the ambient temperature up to $33.8^{\circ} \mathrm{C}$ would increase the transformer hot spot temperature (HST) to $115^{\circ} \mathrm{C}$. This trend could reduce the lifespan of the transformer by a factor of 8 if operated continuously. The study concluded that transformers functioning under such scenario, should not be operated for more than 3 hours daily to avert early ageing of the transformer. A transformer HST mainly depends on the ambient temperature, the rise in the top oil temperature over the ambient temperature and the rise in the winding HST over the top oil temperature [14]. HST values for diverse load conditions can be assessed by suitable computation model on the basis of the transformer's thermal properties as well as the cooling scheme.

In [15], a computational model simulated on MATLAB/Simulink for estimating the loss of life due to the development of hot spot in power transformer was proposed. Results showed that an increase in the transformer temperature beyond thermal limits can reduce its expected lifespan. An empirical investigation was undertaken in [16] to determine the relationship among different parameters (temperature rise, power loss, leading current and efficiency). The study found out that an increase in temperature increases the total power and core losses. The use of transformer oil-based nano-fluid as a means of cooling power distribution transformer was proposed in [17]. Four solid particles $\left(\mathrm{Al}_{2} \mathrm{O}_{3}, \mathrm{Cu}, \mathrm{SiC}\right.$ and $\left.\mathrm{TiO}_{2}\right)$ were utilised to constitute the nanofluids with volume fractions in the range of 1 to $9 \%$ with a step of $2 \%$. Results showed an overall improvement in the cooling performance of transformer compared to the conventional use of pure transformer oil but the SiC-Oil nanofluid gave the lowest transformer temperature. Several investigations [18]-[19] have been carried out in recent time to analyse and characterise factors that could influence the lifespan of a transformer.

A preliminary study on the Asaba business unit of the Benin Electricity Distribution Network has shown that most distribution transformer especially power/distribution transformer recently installed are failing without working for long. The failed transformer test result showed that it was defective on insulation resistance test, which is a function of the oil in the transformer and the oil breakdown voltage was low. Efforts are being made to categorise the essential parameters with respect to ageing as well as to find out possible correlation between the different properties. Such relationships when determined could be able to explain why in recent times, most new power transformers that were newly installed in Benin Electricity Distribution Company Network (Asaba business unit) do fail after working for few months even when such transformers have not been loaded to full capacity. The need to resolve the problem of frequent transformer failure [20], which has become a recurring decimal in the Nigeria power system, has motivated this paper.

This paper investigates the impacts of climatic conditions on distribution transformers. The specific objectives are to determine the effects of ambient temperature change on transformer insulation and the best insulation type for distribution transformers. The findings can assist in the analysis of insulating fluid before energising the transformer. This will help to identify the transformer oil type that is most suitable for use in both low and high temperate regions. As a consequence, the lifetime of the transformer can be extended.

\section{Methods}

The set objectives were achieved based on experimental investigation. First, insulation oil samples were collected from six transformers across the two business units (Ugbowo and Asaba) of Benin Electricity Distribution Company (BEDC) for a period of two months (May and June, 2017). Three different insulation 
oil types (naphtha base mineral, paraffin base mineral and silicon base) were randomly collected from six transformers. These oil samples were subjected to varying degrees of temperature in order to determine the impacts of climatic conditions on the breakdown voltage of power/distribution transformers. Table 1 describes the insulation of each substation. Detailed description of the site meteorology is available in the literature [21]-[22].

\subsection{Oil Sample Collection, Test Procedures and Analysis}

The process of insulation oil samples collection from the various distribution substation and the testing procedures are illustrated in Fig. 1. The samples collected for analysis in the laboratory was done with care to ensure that the insulations represent the product to be sampled. The syringe was attached to sampling value located side of the drain. The system was flush by opening sampling value and moving the handle toward the syringe thereby allowing the oil to flush the tube and stop cock; and pulling the plunger back until the inside syringe is filled with oil. The collected sample was transferred into a labelled container for analysis in the laboratory.

The Megger OTS60PB portable transformer oil tester was utilised to determine the properties of the oil samples. The properties that could be influenced by degradation such as breakdown voltage and the dielectric strength were used to evaluate the transformer performance. The portable oil tester was connected to 230 volts AC supply and a test voltage of $60 \mathrm{kV}$ was applied to the electrode. The observed breakdown take place in an electric arc, which leads to a collapse of the test voltage for each number of tests. A fast switch off was done such that the breakdown was controlled to keep the additional pollution by carbonisation as low as possible. The average value of the test voltage was measured at every instant of the breakdown, represented by the breakdown voltage. At the completion of each test the insulating oil was agitated automatically and the test sequence was repeated four times. The ASTM standards require five or ten results for validity evaluation. The resultant breakdown voltage is the average value of the different measurement from the portable oil tester. Fig. 2 shows the pictorial view of some oil samples and the Megger OST60PB portable oil tester. The test carried out on the oil samples from the different substation with different mineral base oil was subjected to varying degree of temperature using OTS60PB megger oil tester.

Table 1 Geography and Insulation Types of Study Area.

\begin{tabular}{ccccc}
\hline $\begin{array}{c}\text { BEDC } \\
\text { Business Units }\end{array}$ & $\begin{array}{c}\text { Location } \\
(\text { Latitude, Longitude })\end{array}$ & Substation & $\begin{array}{c}\text { Rating } \\
(\mathrm{kVA})\end{array}$ & Insulation Oil \\
\hline Asaba & $6.186^{\circ} \mathrm{N}, 6.733^{\circ} \mathrm{E}$ & COLBON & 300 & $\begin{array}{c}\text { Silicon Base } \\
\text { Egbuna Onwuka }\end{array}$ \\
& $6.185^{\circ} \mathrm{N}, 6.734^{\circ} \mathrm{E}$ & 300 & Paraffin Base Mineral \\
& $6.195^{\circ} \mathrm{N}, 6.741^{\circ} \mathrm{E}$ & Traffic Light & 300 & Naphtha Base Mineral \\
\hline Ugbowo & $6.382^{\circ} \mathrm{N}, 5.611^{\circ} \mathrm{E}$ & Lagos Street & 300 & Paraffin Base Mineral \\
& $6.378^{\circ} \mathrm{N}, 5.606^{\circ} \mathrm{E}$ & Uwagboe & 500 & Silicon Base \\
& $6.381^{\circ} \mathrm{N}, 5.604^{\circ} \mathrm{E}$ & Uwasota & 300 & Naphtha Base Mineral \\
\hline
\end{tabular}

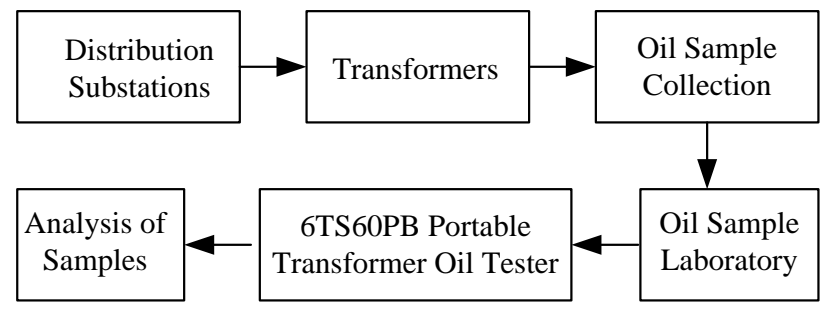

Fig. 1 Schematics of Transformer Oil Samples Collection and Analysis.

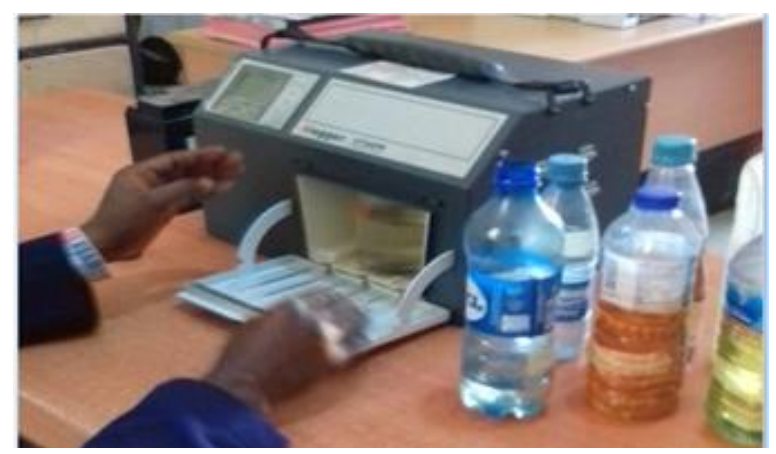

Fig. 2 Pictorial View of Some Oil Samples and the Megger OST60PB Portable Oil Tester Used for Analysis. 


\subsection{Calculation of Average Breakdown Voltage of Oil Sample}

The average breakdown voltage of each insulation oil type is computed as follows:

$V_{b d_{a v e}}=\sum_{n=1}^{N}\left(\frac{V_{b d_{n}}}{n}\right)$,

where, $V_{\text {bdave }}$ is the average breakdown voltage of the oil samples collected $(\mathrm{kV}), V_{\mathrm{bdn}}$ is the breakdown voltage of each oil sample collected $(\mathrm{kV})$, and $N(=5)$ is the total number of tests performed per oil sample.

The dielectric strength is deduced as follows:

$\varepsilon=4 V_{b d_{\text {ave }}}$.

Where, $\varepsilon$ is the dielectric strength of the oil samples collected $(\mathrm{kV} / \mathrm{cm})$.

The mathematical expression of the test result validation (RV) based on ASTM standards (D877) is given in [23] as:

$R V=\frac{R}{V_{b d_{\text {ave }}}} \times 100$.

Where, $R$ is the range of the breakdown voltage of the oil samples collected, which is the difference between the highest and lowest measured test value recorded.

On the basis of the observed (measured) data obtained as described in section 2.1, a third-order polynomial relationship between breakdown voltage and ambient temperature of the form expressed in equation (4) is proposed.

$V_{b d}=\beta_{o}+\beta_{1} T+\beta_{2} T^{2}+\beta_{3} T^{3}$.

Where, $V_{\text {bd }}$ is the breakdown voltage $(\mathrm{kV}), T$ is the ambient temperature $\left({ }^{\circ} \mathrm{C}\right)$ while the coefficients $\beta_{\mathrm{o}}($ at $\mathrm{T}=0)$ and $\beta_{1}-\beta_{3}$ are the interpolation parameter and effect parameters, respectively. Analysis of polynomial regression techniques are available in literatures [24]-[25]. Regression analysis was performed on the proposed model given in equation (4) using Microsoft Excel 2016 [26].

\section{Results and Discussion}

Fig. 3 to Fig. 5 show the variation of the breakdown voltage with temperature at Asaba and Ugbowo business units for the different oil samples. It was observed (Figs. 3 and 4) that as temperature increases there was a corresponding sharp increase in the breakdown voltage within the observed temperature range. The result is an indication of a stable breakdown voltage of the silicon base and paraffin base mineral transformer oil types. This implies that the transformer with these oil types (silicon base and paraffin base mineral) can operate within extreme temperature range with a high dielectric strength. Conversely, the naphtha base mineral transformer oil samples observed for the study sites (Fig. 5) show that the breakdown voltage decreases with increasing temperature. The reduction suggests that at a higher temperature the breakdown voltage will be low. This implies that the transformer with the naphtha base mineral oil cannot provide good insulation at extreme temperature range.
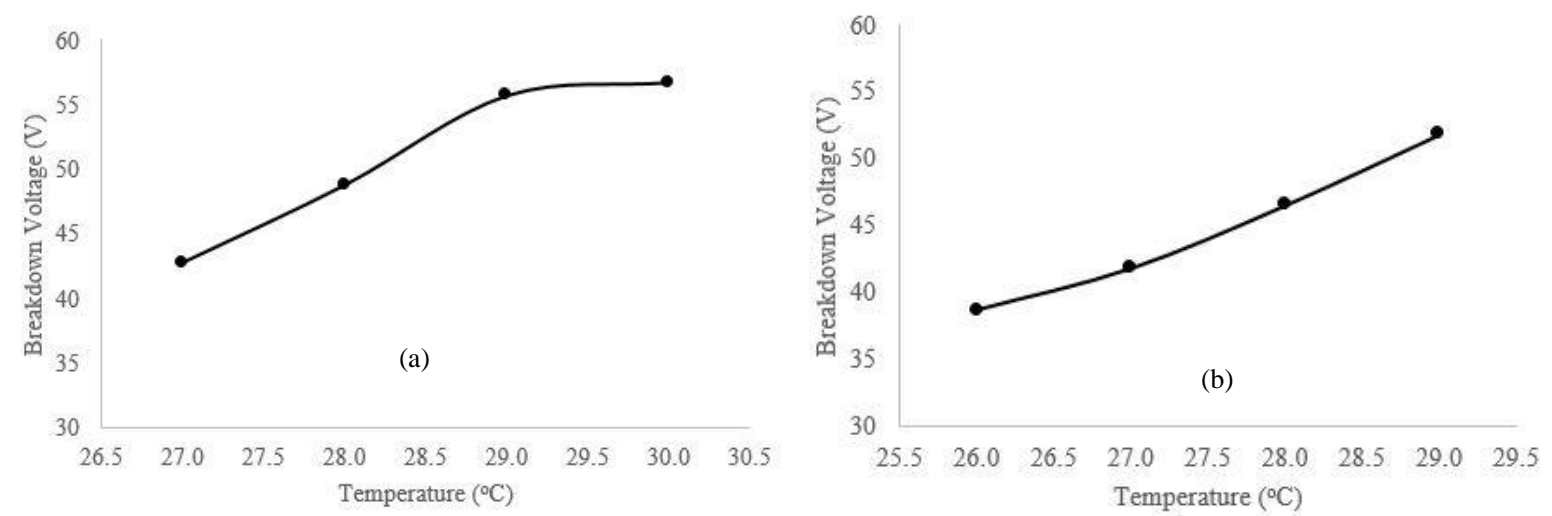

Fig. 3 Variation of Breakdown Voltage of Silicon Base Oil with Ambient Temperature for (a) Asaba Business Unit (b) Ugbowo Business Unit. 

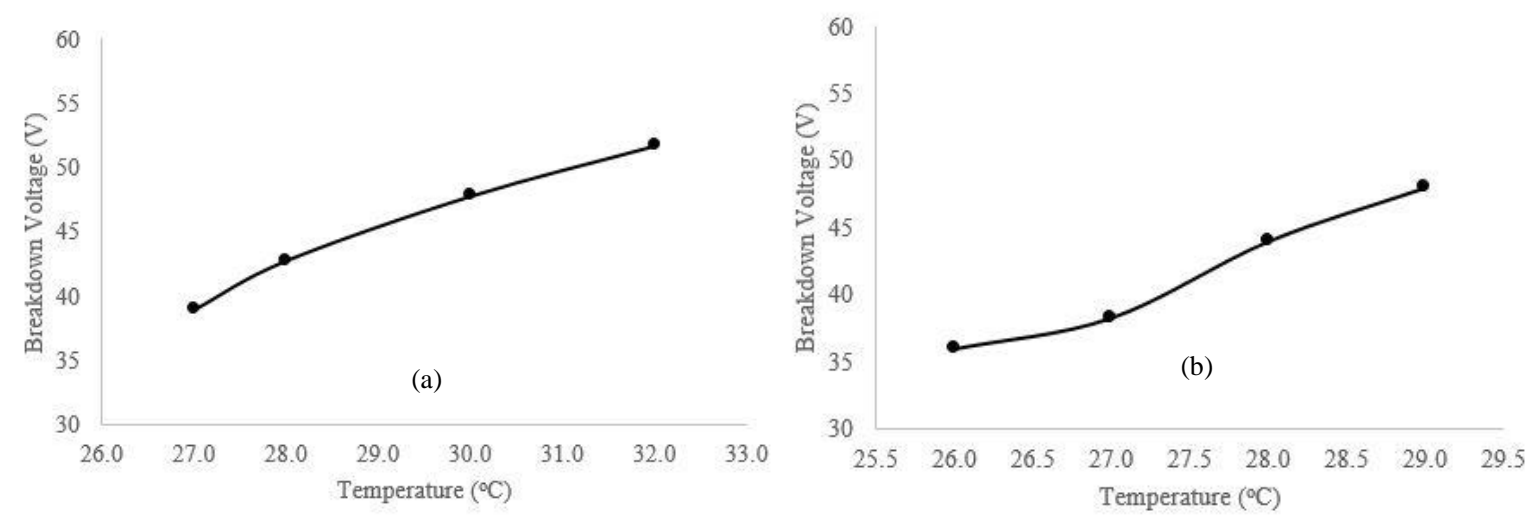

Fig. 4 Variation of Breakdown Voltage of Paraffin Base Mineral Oil with Ambient Temperature for (a) Asaba Business Unit (b) Ugbowo Business Unit.
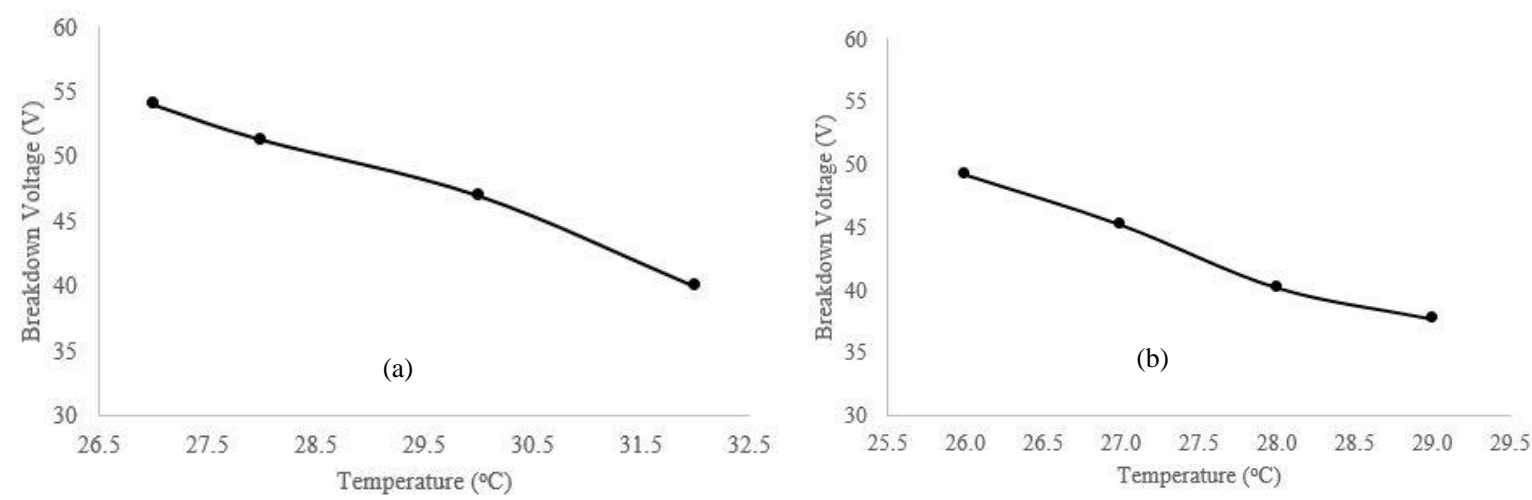

Fig. 5 Variation of Breakdown Voltage of Naphtha Base Mineral Oil with Ambient Temperature for (a) Asaba Business Unit (b) Ugbowo Business Unit.

Table 2 shows the average breakdown voltage and the dielectric strength of the different transformer oil while Table 3 shows the validation results of oil samples. The third-order polynomial model deduced for each of the oil type using regression technique is expressed in Table 4.

Table 2 Summary of Average Breakdown Voltages and Dielectric Strengths of Different Transformer Oil Samples for Study Sites at Observed Ambient Temperature Range $\left(26^{\circ} \mathrm{C}-32^{\circ} \mathrm{C}\right)$.

\begin{tabular}{|c|c|c|c|c|c|c|c|c|c|}
\hline Sample & Substation & $\begin{array}{l}\text { Rating } \\
\text { (kVA) }\end{array}$ & $\begin{array}{l}V_{\text {bd1 }} \\
(\mathrm{kV})\end{array}$ & $\begin{array}{l}\mathrm{V}_{\mathrm{bd} 2} \\
(\mathrm{kV})\end{array}$ & $\begin{array}{l}\mathrm{V}_{\mathrm{bd} 3} \\
(\mathrm{kV})\end{array}$ & $\begin{array}{l}\mathrm{V}_{\mathrm{bd} 4} \\
(\mathrm{kV})\end{array}$ & $\begin{array}{l}\mathrm{V}_{\mathrm{bd} 5} \\
(\mathrm{kV})\end{array}$ & $\begin{array}{l}\mathrm{V}_{\text {bdave }} \\
(\mathrm{kV})\end{array}$ & $\begin{array}{c}\varepsilon \\
(\mathrm{kV} / \mathrm{cm})\end{array}$ \\
\hline \multirow{2}{*}{$\begin{array}{c}\text { Silicon Base } \\
\text { Oil }\end{array}$} & COLBOL & 300 & 44 & 46 & 59 & 60 & 45 & 50.8 & 203.2 \\
\hline & Uwagboe & 500 & 29 & 36 & 46 & 50 & 53 & 42.8 & 171.2 \\
\hline \multirow{2}{*}{$\begin{array}{c}\text { Paraffin Base } \\
\text { Mineral Oil }\end{array}$} & Egbuna Onwuka & 300 & 38 & 40 & 54 & 55 & 39 & 45.2 & 180.8 \\
\hline & Lagos Street & 300 & 26 & 34 & 41 & 46 & 49 & 39.2 & 156.8 \\
\hline \multirow{2}{*}{$\begin{array}{l}\text { Naphtha Base } \\
\text { Mineral Oil }\end{array}$} & Traffic Light & 300 & 30 & 41 & 56 & 56 & 50 & 46.6 & 186.4 \\
\hline & Uwasota & 300 & 26 & 35 & 43 & 46 & 53 & 40.6 & 162.4 \\
\hline
\end{tabular}

Table 3 Result Validation using ASTM Standard (D877).

\begin{tabular}{cccccc}
\hline Sample & Substation & $\begin{array}{c}\text { Rating } \\
(\mathrm{kVA})\end{array}$ & Range, R & $\begin{array}{c}\text { Mean Value, V } \\
(\mathrm{kV})\end{array}$ & $\begin{array}{c}\text { Result Validation, RV } \\
(\%)\end{array}$ \\
\hline Silicon Base & COLBOL & 300 & 16 & 50.8 & 31.5 \\
Oil & Uwagboe & 500 & 24 & 42.8 & 56.1 \\
\hline Paraffin Base & Egbuna Onwuka & 300 & 17 & 45.2 & 37.6 \\
Mineral Oil & Lagos Street & 300 & 23 & 39.2 & 58.7 \\
\hline Naphtha Base & Traffic Light & 300 & 26 & 46.6 & 55.8 \\
Mineral Oil & Uwasota & 300 & 27 & 40.6 & 66.5 \\
\hline
\end{tabular}

As observed (Table 2), the average breakdown voltage of the study area is $46.8 \mathrm{kV}$ (for silicon base transformer oil), $42.2 \mathrm{kV}$ (for paraffin base mineral transformer oil) and $43.6 \mathrm{kV}$ (for naphtha base mineral transformer oil) within the observed temperature range $\left(26^{\circ} \mathrm{C}-32^{\circ} \mathrm{C}\right)$. The result indicates that the mean 
breakdown voltages of the considered transformer oil samples are satisfactory, a minimum of $42.2 \mathrm{kV}$ (for paraffin base mineral oil) and a maximum of $46.8 \mathrm{kV}$ (for silicon base oil). The results suggest that the silicon base transformer oil offers the best transformer insulation for the study area.

Table 4 Developed Models and R-Square Values for Oil Sample Types.

\begin{tabular}{|c|c|c|}
\hline Oil Sample Type & Model & $\mathrm{R}^{2}$ Value \\
\hline Silicon Base & $V_{\mathrm{bd}}=8809.1-952.07 T+34.261 T^{2}-0.4083 T^{3}$ & 0.9995 \\
\hline Paraffin Base Mineral & $V_{\mathrm{bd}}=205.09-31.46 T+1.5056 T^{2}-0.0210 T^{3}$ & 0.9730 \\
\hline Naphtha Base Mineral & $V_{\mathrm{bd}}=-1779.6+186.67 T-6.2451 T^{2}+0.0681 T^{3}$ & 0.9699 \\
\hline
\end{tabular}

The ASTM standards (D877) state that for test results to be considered valid, the range of breakdown voltages recorded must not be more than $92 \%$ of their mean value; otherwise, the test must be repeated. As observed from Table 3, all the values of result validation are less than $92 \%$. Therefore, by ASTM standards, these test results are valid.

The $R$-squared values of the developed models presented in Table 4 show their high prediction accuracy. It is important to state that the transformer life span limitations are centred on the insulation; when subjected to different kind of stresses such as thermal, electromagnetic and mechanical; the insulation weakens continually over time under the influence of atmospheric conditions (oxygen and moisture). The effects of these factors on the insulation in the long run can lead to transformer failure. Hence, the testing of the oil insulation breakdown voltage can be used to determine the dielectric strength. This test stands as a vital component to understanding the behavioural pattern of transformer oil, which are of course being used under different temperate region. If the transformer failure can be predicted with a high degree of precision, unexpected failure can be reduced. Therefore, this paper is significant as it can assist in the analysis of insulating fluid before energising a transformer. This can enable the comparison between normal and abnormal rates of transformer deterioration. In addition, the effect of ambient temperature on transformer insulation as well as the dielectric breakdown voltage at which electrical flashovers can occur in an insulating oil can be determined. This can help to increase the lifespan of distribution transformer.

\section{Conclusion}

The insulation oil of a distribution transformer can accomplish two main functions. It can act as an electrical insulation to resist the high voltages within the transformer. In addition, it serves as a heat dissipation channel to remove the heat generated within the transformer windings. Nevertheless, the insulation weakens continually over time under the influence of atmospheric conditions when subjected to stresses. The overall goal of this paper was to determine the impacts of ambient temperature changes on the oil insulation properties that can influence the degradation such as breakdown voltage and dielectric strength, which can be used to evaluate the effective performance or overall operation of a transformer. The objective was achieved through extensive experimental investigation, transformer oil samples were collected from distribution transformers at Asaba and Ugbowo business units of BEDC. The oil samples were thereafter subjected to varying degrees of temperature, Megger OTS60PB portable oil tester was used to ascertain the properties of the oil samples. Third order polynomial models for predicting the breakdown voltage of different transformer oil types (silicon base, paraffin base mineral and naphtha base mineral) were developed. The results of the test and analysis of the different oil sample showed that silicon transformer oil type is the most suitable to be used at both low and high temperate regions. Paraffin oil has a lower breakdown voltage compared to the silicon transformer oil but could also be suitable within a reasonable range of temperature, while Naphtha transformer oil breakdown voltage tend to reduce as temperature increases making it not suitable for hot weather/temperate regions. The extensive experimental investigations carried out in this paper serve as a vital component that will be of immense assistance in understanding the behavioural pattern of transformer lubricants.

\section{Conflict of Interests}

The authors declare that there is no conflict of interests regarding the publication of this paper.

\section{ORCID}

M. S. Okundamiya (iD https://orcid.org/0000-0003-3365-4759

E. Esekhaigbe (ib) https://orcid.org/0000-0002-5082-4169

J. L. Owa (iD https://orcid.org/0000-0003-2874-0935

H. I. Obakhena (i] https://orcid.org/0000-0003-3944-3506 


\section{References}

[1] M. Darveniza, "Investigations into effective methods for assessing the condition of insulation in aged power transformers," IEEE Transaction on Power Delivery, vol. 13, no. 4, pp. 1214-1223, 1998.

[2] A. J. Vandermaar, "Condition assessment of power transformers," IEEE Power and Energy Society General Meeting - Conversion and Delivery of Electrical Energy in the $21^{\text {st }}$ Century, 2008.

[3] A. J. Christina, M. A. Salam, Q. M. Rahman, F. Wen, S. P. Ang, and W. Voon, "Causes of transformer failures and diagnostic methods - A review,” Renewable and Sustainable Energy Reviews, vol. 82, no. 1, pp. 1442-1456, 2018.

[4] K. S. Senthil, M. Willjuice Iruthayarajan, and M. Bakrutheen, "Analysis of vegetable liquid insulating medium for applications in high voltage transformers," 2014 International Conference on Science Engineering and Management Research, 27-29 November, 2014, Chennai, India.

[5] M. Wang, A. J. Vandermaar, and K. D. Srivastava, "Review of condition assessment of power transformers in service," IEEE Electrical Insulation Magazine, vol. 18, no. 6, pp. 12-25, 2002.

[6] J. Singh, S. Singh, and A. Singh, "Distribution transformer failure modes, effects and criticality analysis," Engineering Failure Analysis, vol. 99, pp. 180-191, 2019.

[7] R. Madavan, and S. Balaraman, "Failure analysis of transformer liquid-solid insulation system under selective environmental conditions using Weibull statistics method," Engineering Failure Analysis, vol. 65, pp. 26-38, 2016.

[8] Y. Hong, W. Q. Meeker, and J. D. McCalley, "Prediction of remaining life of power transformers based on left truncated and right censored lifetime data," The Annals of Applied Statistics, pp. 857-879, 2009.

[9] P. Verma, M. Roy, A. Verma, and V. Bhanot, "Changes in electrical and chemical properties of transformer oil under accelerated thermal stress," International Journal of COMADEM, vol. 8, no. 1, pp. 42-48, 2005.

[10] P. Verma, M. Roy, A. Verma, and V. Bhanot, "Trends in condition monitoring of transformers," Electrical Review, vol. 11, no. 6, pp. 10-18, 2004.

[11] S. T. Jan, R. Afzal, and A. Z. Khan, "Transformer failures, causes and impact," International Conference: Data Mining, Civil and Mechanical Engineering, 2015, Bali, Indonesia, 49 - 52.

[12] M. Akbari, P. Khazaee, and S. P. Karimifard, "Failure modes and effects analysis for power transformers," 28th International Power System Conference, 2013, Tehran, Iran.

[13] M. Hashmi, M. Lehtonen, and S. Hanninen, "Effect of climate change on transformers loading conditions in the future smart grid environment," Open Journal of Applied Sciences, vol. 3, pp. 24-29, 2013.

[14] V. Mehta, and J. Vajpai, "Analysis of hotspot development in power transformer and its life estimation," In: M. Shorif Uddin, A. Sharma, K. L. Agarwal, and M. Saraswat, (eds), Intelligent Energy Management Technologies. Algorithms for Intelligent Systems. Springer, Singapore, 2021.

[15] J. Vajpai, and V. Mehta, "Estimation of loss of life due to hot spot development in power transformer using MATLAB," International Journal of Computing, Communications \& Instrumentation Engineering, vol. 3, no. 1, pp. $29-35,2016$.

[16] Waluyo, S. Saodah, and Rohana, "Investigation of transformer losses and temperature rise," Electrotehnica, Electronica, Automatica, vol. 66, no. 2, pp. 37-44, 2018.

[17] M. I. Hasan, "Using the transformer oil-based nanofluid for cooling of power distribution transformer," International Journal of Energy and Environment, vol. 8, no. 3, pp .229-238, 2017.

[18] A. A. Baba, J. S. Ayodele, O. M. Ameen, A. Jimoh, U. Johnson, B. A. Jimoh, and A. Lawal, "Characterisation and treatment of spent deposited sludge of transformer oil (DSTO) by acid leaching and solvent extraction," Mineral Processing and Extractive Metallurgy, vol. 127, no. 4, pp. 228-235, 2018.

[19] Suwarno, and A. P. Rahman, "Power transformer insulation assessment based on oil-paper measurement data using svm-classifier,” June 2018, doi:10.20944/preprints201806.0002.v1

[20] M. S. Okundamiya, O. S. Udeozor, and O. J. Imade, "Investigation and evaluation of voltage drops: A case study of Guinness and Ikpoba Dam injection substations," International Journal of Electrical and Power Engineering, vol. 3, no. 2, pp. 105-111, 2009.

[21] M. S. Okundamiya, Modelling and Optimization of a hybrid energy system for GSM base transceiver station sites in emerging cities, Ph.D. Thesis, University of Benin, Benin City, Nigeria, 2015.

[22] M. S. Okundamiya, and I. E. Okpamen, "A linear regression model for global solar radiation on horizontal surfaces at Warri, Nigeria," International Journal of Renewable Energy Development, vol. 2, no. 3, pp. 121-126, 2013.

[23] The megger guide to insulating oil dielectric breakdown testing, Art No. 2003-149 - OTS_tg_en_vol. 2, pp. $14,2013$.

[24] Polynomial regression, In: J. O. Rawlings, S. G. Pantula, and D. A. Dickey, (eds), Applied Regression Analysis, Springer Texts in Statistics, Springer, NY, 1998, pp. 235-268, https://doi.org/10.1007/0-387-22753-9_8

[25] J. L. Peixoto, “A property of well-formulated polynomial regression models," The American Statistician, vol. 44, no. 1, 1990, pp. 26-30, https://doi.org/10.2307/2684952

[26] M. S. Okundamiya, and A. N Nzeako, "Estimation of diffuse solar radiation for selected cities in Nigeria," ISRN Renewable Energy, vol. 2011, no. 439410, doi:10.5402/2011/439410 